\title{
Renibacterium salmoninarum gen. nov., sp. nov., the Causative Agent of Bacterial Kidney Disease in Salmonid Fishes $\dagger$
}

\author{
J. E. SANDERS AND J. L. FRYER
}

\author{
Department of Microbiology, Oregon State University, Corvallis, Oregon 97331
}

\begin{abstract}
Isolates of the kidney disease bacterium, the causative agent of bacterial kidney disease in salmonid fishes, were characterized by the guanine plus cytosine content of the deoxyribonucleic acid, by cell wall sugar composition, and by amino acid composition of the peptidoglycan cell wall layer. The guanine plus cytosine contents of the deoxyribonucleic acids of the isolates were $53 \pm 0.46 \mathrm{~mol} \%$. Glucose was the principal cell wall sugar detected in each kidney disease bacterium isolate. The major amino acids detected were alanine, glutamic acid, lysine, and glycine. It is proposed that these organisms form a single species belonging to a new genus, for which the name Renibacterium is proposed. The type species is Renibacterium salmoninarum sp. nov., of which the type strain is Lea-1-74 (= ATCC 33209). This organism is most closely related to the Coryneform Group of Bacteria.
\end{abstract}

Bacterial kidney disease (corynebacterial kidney disease, salmonid kidney disease) was probably first described, under the name Dee disease, in 1930 from Atlantic salmon (Salmo salar) in Scotland (25). This disease was first reported in the United States by Belding and Merrill (2) in brook trout (Salvelinus fontinalis) and brown trout (Salmo trutta) from a hatchery in Massachusetts. In both reports a bacterium, characterized as a small, gram-positive diplobacillus that did not grow on any available media, was found in the kidneys of diseased fish.

Since these original reports, bacterial kidney disease has become widely recognized as one of the most important infectious diseases of hatchery-reared salmonids. It is now routinely found in salmonid populations from parts of Europe, Canada, the United States, Japan, and Iceland. There are no reports of this disease occurring in fishes other than salmonids.

Ordal and Earp (17) initially cultured the causative agent of bacterial kidney disease and identified it on the basis of its morphological appearance, as a species of Corynebacterium. Smith (25) concluded that Dee disease of salmonids in Scotland and bacterial kidney disease were caused by the same bacterium. Since these two publications, no further studies on the classification of the kidney disease bacterium (KDB) have been reported. The fastidious requirements for cultivation and the slow growth of the KDB $(9,17,25)$ have served to limit such research ef-

† Oregon Agricultural Experiment Station Technical Paper no. 5128 . forts. The purpose of this report is to provide additional information pertaining to the taxonomy of, and to propose a name for, this bacterium.

\section{MATERIALS AND METHODS}

Bacterial strains. The bacterial kidney disease isolates used in this study were obtained from diseased salmon at several Oregon Department of Fish and Wildlife hatcheries located in the state of Oregon. Strains RB-1-73 and RB-1-74 were obtained from yearling chinook salmon (Oncorhynchus tshawytscha) at the Round Butte Hatchery; strain Lea-1-74 was obtained from yearling chinook salmon at the Leaburg Hatchery; and strain SR-1-75 was obtained from yearling coho salmon (Oncorhynchus kisutch) at the Siletz Hatchery.

Isolation and media. Each isolate was obtained in pure culture from fish showing typical kidney lesions (29). Material from these lesions was inoculated onto cysteine blood agar modified by substituting calf serum (10 to $20 \%$, vol/vol) for human blood (17). Active cultures of each isolate were maintained on cysteine serum agar in 1-oz (ca. $30-\mathrm{ml}$ ) prescription bottles at 15 or $18^{\circ} \mathrm{C}$ and transferred monthly. Deoxyribonucleic acid (DNA) and purified cell wall preparations were obtained from cells grown on cysteine serum sugar for 20 to 30 days at 15 or $18^{\circ} \mathrm{C}$ in glass culture bottles (surface area, about $170 \mathrm{~cm}^{2}$ ). Immediately before inoculation, 5 to $10 \mathrm{ml}$ of cysteine serum broth was added to each culture bottle to ensure adequate surface moisture during incubation.

Electron microscopy. Cells grown on cysteine serum agar were harvested and washed twice with sterile, double-distilled water. A drop of this washed cell suspension was placed on a polyvinyl-Formvarcoated 300-mesh copper grid. Excess liquid was re- 
moved, and a drop of $2 \%$ phosphotungstic acid was added. Excess liquid was again removed, and the grid was allowed to dry in air. Specimens were examined in a Philips EM-300 electron microscope and were recorded on Kodak electron image plates (Fig. 1).

DNA preparation. For isolation of DNA, 3 to $5 \mathrm{~g}$ (wet weight) of cells was washed once and suspended in 8 to $10 \mathrm{ml}$ of saline-ethylenediaminetetraacetate $(0.15 \mathrm{M} \mathrm{NaCl}$ plus $0.1 \mathrm{M}$ ethylenediaminetetraacetate). The cells were broken with the aid of a French press at 15,000 to $20,000 \mathrm{lb} / \mathrm{in}^{2}$. The cell suspension was passed twice through the pressure cell and centrifuged at $6,780 \times g$ for $15 \mathrm{~min}$, and the DNA-containing supernatant was collected and held at $4^{\circ} \mathrm{C}$. The cell pellet consisted of two distinct layers: a white upper layer composed of broken cells and a lower, lightbrown layer of unbroken cells. The upper layer was suspended and removed with saline-ethylenediaminetetraacetate, and fresh diluent ( 3 to $5 \mathrm{ml}$ ) was added to the pellet of unbroken cells. The suspension of unbroken cells was again passed through the pressure cell, and the supernatant was harvested. This cycle was repeated two or three times more. DNA from the pooled supernatants was purified by the method of Marmur (15) except for the use of saline-ethylenediaminetetraacetate-equilibrated phenol (pH 7.5) in the first deproteinization of the pooled supernatant. The melting temperature $\left(T_{m}\right)$ determinations of DNAs were made in standard saline citrate buffer (15) with a Gilford model 2000 recording spectrophotometer. Each thermal melt contained a reference Escherichia coli WP2 DNA, two KDB DNA preparations, and a double-distilled water control. The DNA was added to the cuvettes at a final concentration of 20 to $40 \mu \mathrm{g} / \mathrm{ml}$. The equation used to relate $T_{m}$ to guanine plus cytosine $(\mathrm{G}+\mathrm{C})$ content was that of Mandel et al. (14).

Composition of cell walls (principal amino acids and amino sugars). Cell walls of the strains tested were isolated and purified by a procedure similar to that of Donegan and Riggs (8). The cells were harvested, washed twice in double-distilled water, and broken with an ultrasonic oscillator (Heat SystemsUltrasonic Inc., model W185). The peptidoglycan was isolated from the cell wall material by the method of Park and Hancock (18), except that the trypsin solution was prepared according to Schleifer and Kandler (24). Amino acids were identified and quantitated on an amino acid analyzer (Beckman, model $121 \mathrm{M}$ ) after hydrolysis in $6 \mathrm{~N} \mathrm{HCl}$ for $22 \mathrm{~h}$ at $110^{\circ} \mathrm{C}$ in an evacuated chamber. The presence of glucosamine and muramic acid was determined by the method of Rondle and Morgan (20) as modified by Nowotny (16). The glucosamine readings were determined immediately by optical density at $530 \mathrm{~nm}$, and the muramic acid was read for optical density at $505 \mathrm{~nm}$, after incubation for $18 \mathrm{~h}$ at $25^{\circ} \mathrm{C}(5,13)$.

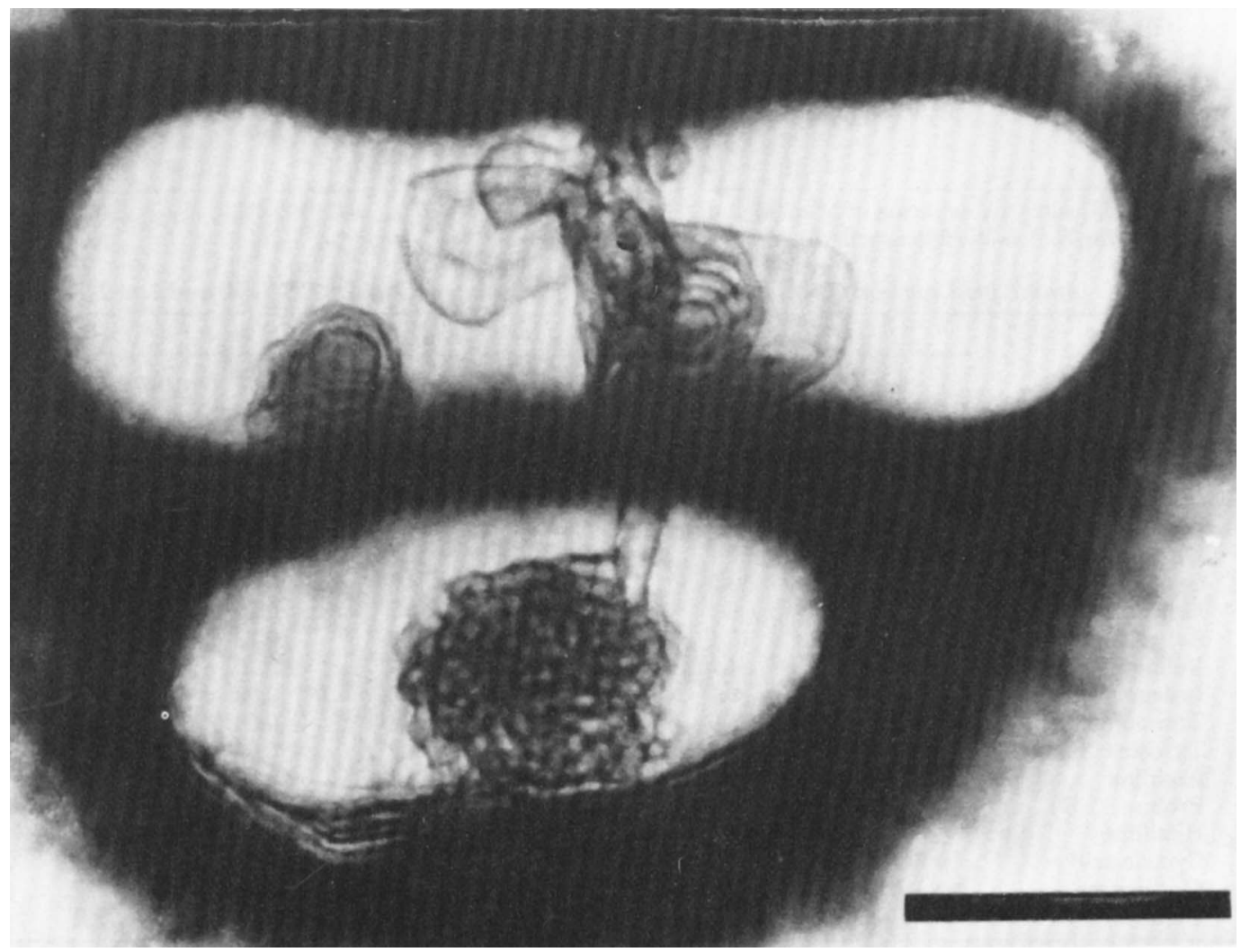

FIG. 1. Electron micrograph of whole cells of KDB isolate RB-1-73 negatively stained with phosphotungstic acid. Note the extensive mesosomes present in each bacterial cell. Bar, $1 \mu \mathrm{m}$. 
Composition of cell walls (principal sugars). Cells were broken, as previously described, with the aid of a French press at 15,000 to $20,000 \mathrm{lb} / \mathrm{in}^{2}$. After centrifugation, the layer of broken cells was removed from the cell pellet. This procedure was repeated twice, and the broken-cell layers were pooled. The procedure for purifying the broken-cell wall suspension in general followed that outlined by Work (31) except that the trypsin was suspended in tris(hydroxymethyl)aminomethane buffer (pH 7.7) and both deoxyribonuclease $(5 \mathrm{mg}$ ) and ribonuclease (10 mg) in tris(hydroxymethyl)aminomethane buffer were used in the final digestion step. Carbohydrates were determined after hydrolysis of each cell wall preparation in $1 \mathrm{~N} \mathrm{HCl}$ for $10 \mathrm{~h}$ in boiling-water bath. Each hydrolysate was neutralized (phenolphthalein) with $\mathrm{NaOH}$ in the cold with rapid mixing and was then freeze dried. Trimethylsilyl derivatives were prepared and were analyzed on a gas chromatographic analyzer (Hewlett-Packard, model 402). Pentoses and methylpentoses were determined by the methods of Dische (6) and Dische and Shettles (7).

\section{RESULTS}

DNA base composition. The average $\mathrm{G}+\mathrm{C}$ contents of the DNAs of isolates RB-1-73, Lea1-74, and SR-1-75 were $52.70,53.52$, and 52.77 mol\%, respectively. The individual $\mathrm{G}+\mathrm{C}$ values and melting temperatures are listed in Table 1. The mean (with standard deviation) of the G+C content of the DNA of the proposed new species is $53.00 \pm 0.46 \mathrm{~mol} \%$.

Amino acid composition of the cell walls. The quantitative amino acid composition of the cell walls of the three KDB isolates is given in Table 2. From 14 to 16 amino acids were detected in measurable amounts in cell wall preparations from each isolate. In all fractions the amino acids found in major quantities were alanine, glutamic acid, lysine, and glycine. Among the amino acids occurring in minor quantities, serine was present in the same relative propor-

TABLE 1. Thermal denaturation data and $G+C$ content for $K D B$ isolates $R B-1 \cdot 73$, Lea-1-74, and $S R-1 \cdot 75$, with $E$. coli WP2 as the standard

\begin{tabular}{cccc}
\hline $\begin{array}{c}\text { KDB } \\
\text { isolate }\end{array}$ & $\begin{array}{c}T_{m} \text { of DNA of } \\
\text { KDB isolate } \\
\left({ }^{\circ} \mathrm{C}\right)\end{array}$ & $\begin{array}{c}T_{m} \text { of } E \\
\text { coli WP2 } \\
\left({ }^{\circ} \mathrm{C}\right)\end{array}$ & $\begin{array}{c}\text { G+C of DNA } \\
\text { of KDB isolate } \\
(\mathrm{mol} \%)\end{array}$ \\
\hline RB-1-73 & 75.36 & 74.39 & 52.93 \\
Lea-1-74 & 74.99 & 74.25 & 52.47 \\
SR-1-75 & 75.09 & 73.75 & 53.49 \\
& 75.03 & 73.75 & 53.55 \\
& 75.23 & 74.39 & 52.67 \\
\hline
\end{tabular}

${ }^{a}$ Calculated using the equation of Mandel et al. (14): $\% \mathrm{G}+\mathrm{C}_{x}=\% \mathrm{G}+\mathrm{C}_{E . \text { coli }}+0.0199\left(T_{m[x]}-T_{m[E . c o l i]}\right) \times 100$, where $\mathrm{G}+\mathrm{C}$ for $E$. coli WP2 is exactly $51 \mathrm{~mol} \%$.

TABLE 2. Amino acid composition of cell walls of the $K D B$ isolates $R B-1-73, R B-1-74$, and Lea-1-74

\begin{tabular}{|c|c|c|c|c|c|c|}
\hline \multirow{3}{*}{$\begin{array}{l}\text { Cell wall } \\
\text { amino acid }\end{array}$} & \multicolumn{6}{|c|}{ Concn of amino acids present in cell walls } \\
\hline & \multicolumn{2}{|c|}{ RB-1-73 } & \multicolumn{2}{|c|}{ RB-1-74 } & \multicolumn{2}{|c|}{ Lea-1-74 } \\
\hline & $\mu \mathrm{M} / \mathrm{mg}$ & $\mu g / \mathrm{mg}$ & $\mu \mathbf{M} / \mathbf{m g}$ & $\mu \mathrm{g} / \mathrm{mg}$ & $\mu \mathbf{M} / \mathbf{m g}$ & $\mu g / \mathrm{mg}$ \\
\hline Alanine & 3.85 & 343.0 & 2.63 & 234.0 & 3.06 & 272.5 \\
\hline Glutamic acid & 1.07 & 157.1 & 1.02 & 149.3 & 1.11 & 161.6 \\
\hline Lysine & 0.88 & 128.1 & 0.80 & 117.4 & 0.90 & 131.2 \\
\hline Glycine & 0.88 & 65.7 & 0.96 & 72.4 & 1.07 & 80.2 \\
\hline Serine & 0.18 & 18.5 & 0.33 & 34.3 & 0.24 & 25.7 \\
\hline Leucine & 0.07 & 9.7 & 0.26 & 33.7 & 0.16 & 21.1 \\
\hline Aspartic acid & 0.07 & 10.1 & 0.24 & 32.7 & 0.12 & 16.1 \\
\hline Valine & 0.04 & 4.2 & 0.19 & 22.1 & 0.10 & 12.3 \\
\hline Isoleucine & 0.05 & 6.1 & 0.15 & 20.0 & 0.09 & 11.5 \\
\hline Threonine & 0.04 & 5.0 & 0.14 & 16.4 & 0.09 & 10.5 \\
\hline Tyrosine & 0.23 & 41.9 & 0.08 & 14.2 & 0.05 & 9.4 \\
\hline Arginine & $\mathrm{T}^{b}$ & $\mathbf{T}$ & 0.07 & 13.0 & 0.05 & 9.4 \\
\hline Proline & 0.05 & 5.4 & 0.10 & 11.6 & 0.06 & 6.9 \\
\hline Histidine & $\mathrm{T}$ & $\mathbf{T}$ & 0.04 & 6.8 & 0.02 & 2.8 \\
\hline Cysteic acid & 0.01 & 2.1 & 0.01 & 2.2 & 0.01 & 2.4 \\
\hline Methionine & 0.01 & 2.0 & 0.01 & 1.4 & 0.01 & 1.4 \\
\hline Cystine & $T$ & $T$ & $\mathrm{~T}$ & $T$ & $T$ & $\mathrm{~T}$ \\
\hline
\end{tabular}

\footnotetext{
${ }^{a}$ Optical rotations of the amino acids were not determined.
}

${ }^{b} \mathrm{~T}$, Trace. 
tion in each isolate. The other amino acids detected were present in amounts which varied considerably among the different isolates.

Neutral and amino sugar composition of the cell walls. The cell wall of each KDB isolate contained the neutral sugars rhamnose, mannose, glucose, and arabinose and the amino sugars glucosamine and muramic acid (Table 3). Among the neutral sugars, glucose was the principal component of each $\mathrm{KDB}$ isolate; it varied in concentration from $40.9 \mu \mathrm{g} / \mathrm{mg}$ in the Lea-174 isolate to $123 \mu \mathrm{g} / \mathrm{mg}$ in RB-1-73. Compared to glucose, the other sugars were detected in considerably smaller amounts (2.4 to $24.1 \mu \mathrm{g} /$ $\mathrm{mg}$ ). Glucosamine and muramic acid were detected at concentrations ranging from 121.3 to 155.8 and 98.6 to $122.5 \mu \mathrm{g} / \mathrm{mg}$, respectively.

Molar ratios of the principal cell wall amino acids and amino sugars. The molar ratios of the principal cell wall amino acids (Table 2) and amino sugars (Table 3) are given in Table 4. These values were calculated as molar ratios to glucosamine, even though alanine was present in considerably greater concentrations. The molar ratios of muramic acid to glucosamine vary from 0.5 to 0.6 , strongly suggesting alternating glucosamine and muramic acid units in the glycan moiety. The "major" amino acids-lysine, glutamic acid, glycine, and alanine-occurred in molar ratios of about 1:1:1: 3-5. All of the KDB isolates contain lysine as their principal diamino acid. In addition, the presence of $1 \mathrm{~mol}$ of glycine and such large amounts of alanine suggests that their location in the interpeptide bridges is between the peptidoglycan subunits.

\section{DISCUSSION}

Barksdale (1) and the most recent edition of Bergey's Manual (19) have given ample evidence demonstrating that the various members of the Coryneform Group of Bacteria cannot be distinguished on the basis of cellular morphology alone. Ordal and Earp (17) originally suggested a relationship of KDB to the genus Corynebacterium based in part on pleomorphic characteristics of the cells. Young and Chapman (32) recently indicated a consistent rod form with KDB cells grown in culture and more irregularity with those growing in host tissues. It is our general observation that pleomorphism among $\mathrm{KDB}$, whether in culture or host tissues, occurs only to a minor extent and probably reflects more closely variations in the growth cycle or host response, or both, rather than any basic morphological characteristic (Fig. 2).

In the latest edition of Bergey's Manual (19), the critical characteristics considered essential for the human and other-animal pathogenic corynebacteria (Section I) are discussed. These include the presence of a peptidoglycan containing alanine, glutamic acid, and meso-diaminopimelic acid and a polymer containing arabinose and galactose in the cell wall. In addition, the presence of mycolic acids is another property of considerable taxonomic significance.

Cell wall analysis indicates that each of the

TABLE 3. Chemical analysis of cell walls of the KDB isolates RB-1-73, Lea-1-74, and SR-1-75

\begin{tabular}{lcccccrc}
\hline & \multicolumn{5}{c}{ Concn of neutral and amino sugars in cell walls } \\
\cline { 2 - 7 } Constituent & \multicolumn{2}{c}{ RB-1-73 } & \multicolumn{2}{c}{ Lea-1-74 } & \multicolumn{2}{c}{ SR-1-75 } \\
\cline { 2 - 7 } & $\mu \mathrm{M} / \mathrm{mg}$ & $\mu \mathrm{g} / \mathrm{mg}$ & $\mu \mathrm{M} / \mathrm{mg}$ & $\mu \mathrm{g} / \mathrm{mg}$ & $\mu \mathrm{M} / \mathrm{mg}$ & $\mu \mathrm{g} / \mathrm{mg}$ \\
\hline Rhamnose & 0.05 & 9.4 & 0.06 & 11.7 & 0.06 & 11.7 \\
Mannose & 0.05 & 9.4 & 0.04 & 8.0 & 0.01 & 2.4 & 54.0 \\
Glucose & 0.69 & 123.0 & 0.23 & 40.9 & 0.30 & 17.6 \\
Arabinose & 0.06 & 8.5 & 0.16 & 24.1 & 0.12 & 122.5 \\
Muramic acid & 0.39 & 98.6 & 0.47 & 117.7 & 0.49 & 153.8 \\
Glucosamine & 0.68 & 121.3 & 0.87 & 155.8 & 0.86 & 156 \\
\hline
\end{tabular}

TABLE 4. Comparison of the quantitative amino acid and amino sugar compositions of the cell walls of KDB isolates Lea-1-74, RB-1-73, and RB-1-74

\begin{tabular}{cccccccc}
\hline & \multicolumn{1}{c}{ Molar ratios $^{a}$} \\
\cline { 2 - 7 } Isolate & Lysine & $\begin{array}{c}\text { Glutamic } \\
\text { acid }\end{array}$ & Glycine & Alanine & Serine & Glucosamine & $\begin{array}{c}\text { Muramic } \\
\text { acid }\end{array}$ \\
\hline Lea-1-74 & 1.0 & 1.3 & 1.2 & 3.5 & 0.3 & 0.3 & 1.0 \\
RB-1-73 & 1.3 & 1.6 & 1.3 & 5.7 & 0.3 & 1.0 & 0.6 \\
RB-1-74 & 0.9 & 1.2 & 1.1 & 3.0 & 0.4 & ND $^{b}$ \\
\hline
\end{tabular}

${ }^{a}$ Expressed in relation to glucosamine.

${ }^{b} \mathrm{ND}$, Not determined. 


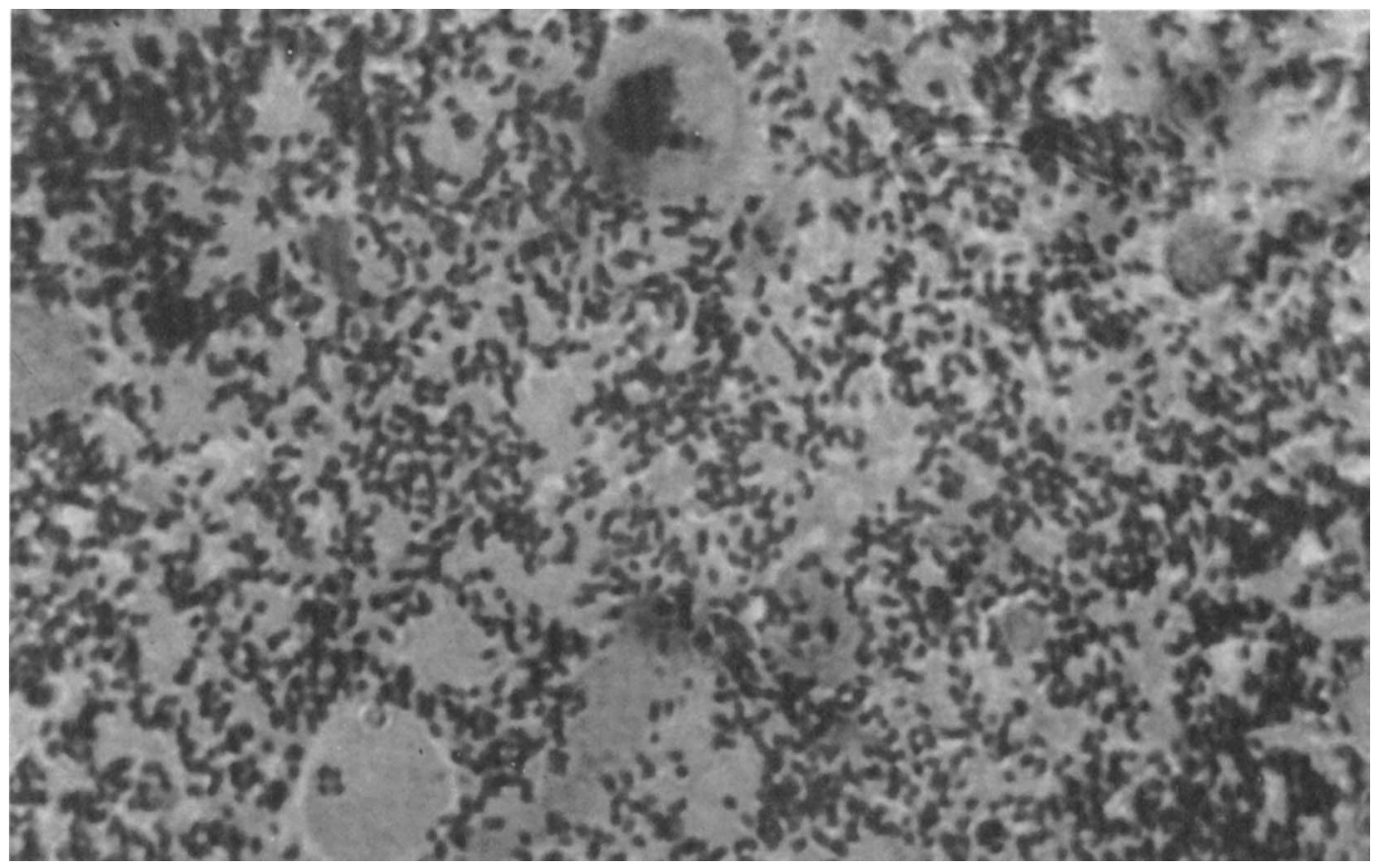

FIG. 2. Gram-stain preparation of a kidney smear from a spring chinook salmon (Oncorhynchus tshawytscha) heavily infected with the KDB. Magnification, $\times 1,000$.

KDB isolates contains a peptidoglycan considerably different from that described for the human and other-animal pathogenic corynebacteria. In addition, no galactose and only minor amounts of arabinose were found in cell wall hydrolysates. Glucose was the principal sugar detected. The presence of mycolic acids was not determined in this study; however, Goodfellow et al. (10) recently reported the absence of mycolic acids in a strain of KDB (H14) obtained from the U.S. Fish and Wildlife Service, Eastern Fish Disease Laboratory, Leetown, W.Va. These observations strongly indicate that the KDB isolates should not be included with the genus Corynebacterium as originally suggested by $\mathrm{Or}$ dal and Earp (17).

Bullock et al. (4) have suggested a resemblance between KDB and members of the genus Listeria; however, the $\mathrm{G}+\mathrm{C}$ content of the DNA of KDB $(53 \pm 0.46 \mathrm{~mol} \%)$ differs markedly from that reported for the family Listeriaceae (38 to $42 \mathrm{~mol} \%$ [27]). Further, the cell wall peptidoglycan of Listeria monocytogenes contains mesodiaminopimelic acid, aspartic acid, and leucine, which were not detected in the KDB isolates. The relationship between KDB and Listeria denitrificans is less clear, although it should be pointed out that several investigators $(12,27)$ have suggested that the latter be relocated in the Coryneform Group of Bacteria.
The KDB isolates also do not closely resemble members of the genus Erysipelothrix. The latter have a tendency to form long filaments, are catalase negative, and have a $\mathrm{G}+\mathrm{C}$ content of about $36 \mathrm{~mol} \%$.

The generic classification of KDB within the Coryneform Group of Bacteria is complicated by the numerous taxonomic problems encountered with this diverse group (19). Jones (12), in a numerical taxonomy study, indicated that the family Corynebacteriaceae contained five or six taxa worthy of genus rank. Two of these genera clustered around Corynebacterium pyogenes and $L$. denitrificans. The $L$. denitrificans group was identified more closely with the genus $A r$. throbacter, which has characteristics quite different from those of the KDB isolates. The generic classification of $C$. pyogenes has been considered questionable for a considerable period of time $(1,11,12,19)$. C. pyogenes and the closely related Corynebacterium haemolyticum have a G+C content of $58 \pm 1.0 \mathrm{~mol} \%$, have rhamnose and glucose as their cell wall sugars, contain alanine, glutamic acid, and lysine in the cell wall peptidoglycan, and, according to Goodfellow et al. (10), do not possess mycolic acids. The KDB isolates share these cell wall characteristics; however, they do not react to Lancefield group $G$ antisera, and they have a lower $\mathrm{G}+\mathrm{C}$ value and a different optimum tempera- 
ture for growth (25) and pathogenesis (23).

We therefore propose the establishment of a new genus, Renibacterium (Re.ni.bac.te'ri.um. L.n. renes the kidneys; Gr. neut. n. bakterion small rod; M.L. neut. n. Renibacterium kidney bacterium), for this organism. Because the four isolates described here varied only in the amounts of cell wall amino acids and sugars detected, it is proposed that these organisms represent variants of the same species, for which we propose the name Renibacterium salmoninarum sp. nov. (sal.mo.ni.na'rum. M.L. Salmoninae subfamily of the Salmonidae; M.L. gen. $\mathrm{n}$. salmoninarum, of the Salmoninae). Until more definite evidence becomes available, we suggest that Renibacterium is most closely related to members of the Coryneform Group of Bacteria. Formal descriptions of the genus, species, and type strain, based on our results and those of previous investigators, follow.

Renibacterium gen. nov. Short rods, 0.3 to 1.0 by 1.0 to $1.5 \mu \mathrm{m}$, often occurring in pairs. Strongly gram positive. Not acid fast. Nonencapsulated. Nonmotile. Endospores are absent. Aerobic. Temperature for optimum growth: 15 to $18^{\circ} \mathrm{C}$; slow growth occurs at 5 and $22^{\circ} \mathrm{C}$; no growth occurs at $37^{\circ} \mathrm{C}$. Catalase positive. The $\mathrm{G}+\mathrm{C}$ content of the DNA is $53.0 \mathrm{~mol} \%$. The cell wall composition is characterized by lysine as the diamino acid of the peptidoglycan. The principal cell wall sugar is glucose. Occurs among populations of salmonid fishes in North America, Europe, and Asia. The type species is $R$. salmoninarum sp. nov.

Renibacterium salmoninarum sp. nov. Short rods, 0.3 to 1.0 by 1.0 to $1.5 \mu \mathrm{m}$, often occurring in pairs. Strongly gram positive. Not acid fast. Nonmotile. Nonencapsulated. Endospores are absent.

Smith (25) described the colony characteristics on several media. On cysteine serum agar the colonies are circular and convex, white to creamy yellow, and of varying sizes. On Loeffler coagulated serum a creamy growth with a matt surface is produced. With Dorset egg medium, growth appears as a raised, smooth, shiny yellow layer. On cysteine serum broth, creamy-yellow growth occurs only at the surface of the medium. Growth on all media is slow, often requiring several weeks of incubation.

Grows very slowly at 5 and $22^{\circ} \mathrm{C}$; no growth occurs at $37^{\circ} \mathrm{C}(25)$. Optimal growth occurs at 15 to $18^{\circ} \mathrm{C}$. Maximum cell yields are obtained after 20 to 30 days of incubation at 15 to $18^{\circ} \mathrm{C}$ at pH 6.5 to 7.5 .

Aerobic. There is no apparent acid production from sugars. All strains require cysteine for growth. The majority of strains also require serum or whole blood for growth. Catalase pos- itive (activity inhibited by $0.01 \mathrm{M}$ sodium azide). Cytochrome-oxidase negative. Does not liquefy gelatin (25). Proteolysis without any $\mathrm{pH}$ change is produced in litmus milk (25).

The $\mathrm{G}+\mathrm{C}$ content of the DNA is $53.0 \mathrm{~mol} \%$.

The cell wall peptidoglycan contains glutamic acid, lysine, alanine, and glycine. The principal cell wall sugar is glucose; arabinose, rhamnose, and mannose are also present. Mycolic acids are not present in at least one strain (10).

Serological tests with 10 strains of this bacterium isolated from various locations in the United States and Canada showed all to be antigenically homologous (3). Does not crossreact to Lancefield group $G$ streptococcal antisera.

Produces a slowly developing chronic infection characterized by gray-white, enlarged necrotic abscesses in the kidney (29). Young and Chapman (32) indicated that the pathological changes in the fine structure of both the glomerulus and renal tubules resemble those observed in mammalian glomerulonephritis and nephrotic syndrome.

Susceptible to chloramphenicol (26), erythromycin (28), and sulfonamides $(21,22,30)$.

Occurs among populations of salmonid fishes in North America, Europe, and Asia. This bacterium has only been isolated from members of Salmoninae, the salmon, trout, and char, of the family Salmonidae.

Type strain: Lea-1-74 (= ATCC 33209). The description of the type strain is as follows. Short rods, 0.3 to 1.0 by 1.0 to $1.5 \mu \mathrm{m}$, often occurring in pairs. Strongly gram positive. Not acid fast. Nonmotile. Nonencapsulated. Endospores are absent.

On cysteine serum agar the colonies are circular and convex, white, and of varying sizes. Growth is slow, often requiring several weeks of incubation. Optimal growth occurs at 15 to $18^{\circ} \mathrm{C}$. Maximum cell yields are obtained after 20 to 30 days of incubation at 15 to $18^{\circ} \mathrm{C}$ at $\mathrm{pH} 6.5$ to 7.5.

Aerobic. There is no apparent acid production from glucose. Cysteine is required for growth. The majority of strains also require serum for growth. Catalase positive. Cytochrome-oxidase negative.

The $\mathrm{G}+\mathrm{C}$ content of the DNA is $53.5 \mathrm{~mol} \%$.

The cell wall peptidoglycan contains glutamic acid, lysine, alanine, and glycine. The principal cell wall sugar is glucose; arabinose, rhamnose, and mannose are also present.

\section{ACKNOWLEDGMENTS}

This work was supported by the Oregon Department of Fish and Wildlife under PL 89304, Anadromous Fish Act.

We thank R. Becker, Department of Biochemistry, and R. Seidler and A. Anderson, Department of Microbiology, Oregon State University, for their assistance. 


\section{REPRINT REQUESTS}

Address reprint requests to: Dr. J. E. Sanders, Department of Microbiology, Oregon State University, Corvallis, OR 97331.

\section{LTERATURE CITED}

1. Barksdale, L. 1970. Corynebacterium diphtheriae and its relatives. Bacteriol. Rev. 34:378-422.

2. Belding, D. L., and B. Merrill. 1935. A preliminary report upon a hatchery disease of the Salmonidae. Trans. Am. Fish. Soc. 65:76-84.

3. Bullock, G. L., H. M. Stuckey, and P. K. Chen. 1974. Corynebacterial kidney disease of salmonids: growth and serological studies on the causative bacterium. Appl. Microbiol. 28:811-814.

4. Bullock, G. L., H. M. Stuckey, and K. Wolf. 1975. Bacterial kidney disease of salmonid fishes. Fish and Wildlife Service Fish Diseases Leaflet no. 41. U.S. Department of the Interior, Washington, D.C.

5. Crumpton, M. J. 1959. The identification of amino sugars. Biochem. J. 72:479-486.

6. Dische, Z. 1949. Spectrophotometric method for the determination of free pentose and pentose in nucleotides. J. Biol. Chem. 181:379-392.

7. Dische, Z., and L. B. Shettles. 1948. A specific color reaction of methyl pentoses and a spectrophotometric micromethod for their determination. J. Biol. Chem. 175:595-603.

8. Donegan, E. A., and H. G. Riggs. 1974. In vitro incorporation of serine into the staphylococcal cell wall. Infect. Immun. 10:264-269.

9. Evelyn, T. P. T. 1978. An improved growth medium for the kidney disease bacterium and some notes on using the medium. Bull. Off. Int. Epiz. 87:511-513.

10. Goodfellow, M., M. D. Collins, and D. E. Minnikin. 1976. Thin-layer chromatographic analysis of mycolic acid and other long-chain components in,whole organism methanolysates of coryneform and related taxa. J. Gen. Microbiol. 96:351-358.

11. Harrington, B. J. 1966. A numerical taxonomical study of some corynebacteria and related organisms. J. Gen. Microbiol. 54:31-40.

12. Jones, D. 1975 . A numerical taxonomic study of coryneform and related bacteria. J. Gen. Microbiol. 87:52-96.

13. Krause, R. M., and M. McCarty. 1961. Studies on the chemical structure of streptococcal cell wall. 1 . The identification of a mucopeptide in the cell wall of group $A$ and $A$ variant streptococci. J. Exp. Med. 114:127140.

14. Mandel, M., L. Igambi, J. Bergendahl, M. Dodson, and E. Scheltger. 1970. Correlation of melting temperature and cesium chloride buoyant density of bacterial deoxyribonucleic acid. J. Bacteriol. 101:333-338.

15. Marmur, J. 1961. A procedure for the isolation of deoxyribonucleic acid from microorganisms. J. Mol. Biol. 3: 208-218.
16. Nowotny, A. 1969. Basic exercises in immunochemistry. Springer-Verlag, New York.

17. Ordal, E. J., and B. J. Earp. 1956. Cultivation and transmission of the etiological agent of kidney disease in salmonid fishes. Proc. Soc. Exp. Biol. Med. 92:85-88.

18. Park, J. T., and R. Hancock. 1960. Fractionation procedure for studies of the synthesis of cell-wall mucopeptide and of other polymers in cells of Staphylococcus aureus. J. Gen. Microbiol. 22:249-258.

19. Rogosa, M., C. S. Cummins, R. A. Lelliott, and R. M. Keddie. 1974. Coryneform group of bacteria, p. 599632. In R. E. Buchanan and N. E. Gibbons (ed.), Bergey's manual of determinative bacteriology, 8 th ed. The Williams and Wilkins Co., Baltimore.

20. Rondle, C. J., and W. T. Morgan. 1955. The determination of glucosamine and galactosamine. Biochem. J. 61:586-589.

21. Rucker, R. R., A. F. Bernier, W. J. Whipple, and R. E. Burrows. 1951. Sulfadiazine for kidney disease. Prog. Fish-Cult. 13:135-137.

22. Rucker, R. R., B. J. Earp, and E. J. Ordal. 1954. Infectious diseases of Pacific salmon. Trans. Am. Fish. Soc. 83:297-312.

23. Sanders, J. E., K. S. Pilcher, and J. L. Fryer. 1978. Relation of water temperature to bacterial kidney disease in coho salmon (Oncorhynchus kisutch), sockeye salmon (O. nerka), and steelhead trout (Salmo gairdneri). J. Fish. Res. Board Can. 35:8-11.

24. Schleifer, K. H., and O. Kandler. 1972. Peptidoglycan types of bacterial cell walls and their taxonomic implications. Bacteriol. Rev. 36:407-477.

25. Smith, I. W. 1964. The occurrence and pathology of Dee Disease. Freshwater Salmon Fish Res. 34:1-12.

26. Snieszko, S. F., and P. J. Grifinn. 1955. Kidney disease in brook trout and its treatment. Prog. Fish-Cult. 17:313.

27. Stuart, S. E., and H. J. Welshimer. 1973. Taxonomic reexamination of Listeria Pirie and transfer of Listeria grayi and Listeria murrayi to a new genus, Murraya. Int. J. Syst. Bacteriol. 24:177-185.

28. Wolf, K., and C. E. Dunbar. 1959. Test of 34 therapeutic agents for control of kidney disease in trout. Trans. Am. Fish. Soc. 88:117-124.

29. Wood, E. M., and T. Yasutake. 1956. Histopathology of kidney disease in fish. Am. J. Pathol. 32:845-857.

30. Wood, J. W., and J. Wallis, 1955. Kidney disease in adult chinook salmon and its transmission by feeding to young chinook salmon. Res. Brief Fish. Comm. Oregon 6:32-40.

31. Work, E. 1971. Cell walls. Methods Microbiol. 5A:361418.

32. Young, C. L., and G. B. Chapman. 1978. Ultrastructura] aspects of the causative agent and renal histopathology of bacterial kidney disease in brook trout (Salvelinus fontinalis). J. Fish. Res. Board Can. 35:1234-1248. 